\title{
Reactive Oxygen Species, Interferon and Antiviral Innate Immune Response in Nasal Mucosa
}

\author{
Seung-No Hong and Hyun Jik Kim \\ Department of Otorhinolaryngology, Seoul National University College of Medicine, Seoul, Korea
}

\section{비강 점막의 활성 산소, 인터페론 그리고 항바이러스 선천성 면역반응}

홍 승 노·김 현 직

서울대학교 의과대학 이비인후과학교실

Received June 3, 2015 Accepted July 31,2015 Address for correspondence Hyun Jik Kim, MD, PhD Department of Otorhinolaryngology, Seoul National University College of Medicine, 101 Daehak-ro, Jongno-gu, Seoul 03080, Korea Tel $+82-2-2072-2203$

Fax $+82-2-735-2387$

E-mail hyunjerry@snu.ac.kr
The regulated production of reactive oxygen species (ROS) has been considered a unique property of phagocytic cells which use this ROS system to induce innate defense system that enables it to successfully combat the pathogens. However, the mechanisms for how respiratory mucosa might produce ROS against respiratory viral infection still need to be completely defined. Respiratory mucosa and nasal epithelium has been known as the first defense site of human respiratory tract which is highly exposed and vulnerable to environmental pathogens, including air-bone microbes, viruses and allergens. We are especially interested in the innate immune response to respiratory virus infection in nasal epithelium and how this response might be influenced by ROS generation after viral infection. The interferon (IFN) signaling system is perhaps the most critical pathway for antiviral defense and protective actions of IFNs rely on signaling through IFN receptors, transcription factors and IFN-stimulated genes or antiviral cytokines requiring for virus degradation and suppression of viral transcription or translation. We verified that both type I and type III IFN genes expression and secreted proteins were more highly induced after influenza A virus infection in nasal epithelium. We also propose that type III IFNs are the primary IFNs to mediate an anti-viral defense in nasal epithelium and more sensitively reacted with ROS which were produced after respiratory virus infection. We estimate that ROS are necessary for the innate immune response and trigger the induction of IFN-related innate immune response to resist respiratory virus infection in human respiratory mucosa.

Korean J Otorhinolaryngol-Head Neck Surg 2015;58(11):739-43

Key Words Innate immunity $\cdot$ Interferon $\cdot$ Nasal mucosa $\cdot$ Reactive oxygen species.

\section{서 론}

비강 점막을 포함한 호흡기 점막은 다양한 호흡기 바이러 스의 침입 및 감염 활성화에 저항하는 우리 몸의 첫 번째 방 어 기관이며, 바이러스의 침입이 감지되면 바이러스의 감염 을 억제시키기 위한 방어기전, 특히 선천성 면역 체계가 비강 및 호흡기 점막에서 활성화된다고 알려지고 있다.,2)

특히 비강 점막은 하부호흡기 점막에 비해 혈관의 분포가 상대적으로 높고 신경 분포가 다양하여 외부자극에 보다 민 감하게 반응하며 외부 병원균과 만나는 첫 번째 타겟 조직이
다. 비강 상피에 존재하는 섬모 및 점액에 의해서도 이러한 병원균을 걸러낼 수 있고 특히 비강 점막에 분포하는 점액에 다양한 항균 물질을 함유하고 있어 각종 박테리아에 의한 감염에 대항하게 된다. 하지만 호흡기 바이러스 감염은 이러 한 항균 기전에 의해서 억제하기 어렵고, 약제에도 잘 반응하 지 않는 독특한 형태의 감염을 일으키고 변종 바이러스에 의 한 집단 감염을 유발하기도 하여 그 심각성이 점차 증가하고 있다. ${ }^{3,4)}$

많은 연구자들에 의해 이러한 바이러스 감염에 저항하는 인체 면역 체계에 대한 연구가 이루어지고 있으며, 특히 호흡 
기, 소화기, 비뇨기 등 병원균과 직접 접촉하는 상피조직을 보 유한 기관에서는 점막 면역 체계가 발달되어 있고, 특히 선천 성 면역 기전과 밀접한 관계가 있어 바이러스 감염 억제 기전 연구 및 백신 개발에 이용되고 있다.5)

바이러스 감염이 비강 점막에 노출되면 바이러스의 사멸 을 위해 우리 몸의 면역 체계가 활성화 되는데, 특히 비강 점 막은 외부 바이러스의 1차 접촉 기관이고 방어막 역할을 하기 때문에 비강 점막에서의 면역 체계 및 면역 기전 활성화 연구 는 바이러스성 감염 질환 치료 연구에 매우 중요하다. 하지만 비강 점막의 선천성 면역 체계와 활성화 기전 및 매개 물질에 대해서는 아직 확실한 규명이 부족한 상태이다.

\section{본 론}

\section{Interferon}

우리 몸의 면역 체계는 선천성 면역과 후천성 면역으로 나 뉘며 특히 선천성 면역 체계는 바이러스를 포함한 외부 병원 균들과 직접 접촉을 하는 비강, 호흡기, 소화기, 생식기 등의 점막에서 중요한 역할을 수행한다고 알려져 있다. 그 중 비강 점막은 바이러스가 침입하면 그 바이러스를 인식하고 바이러 스에 저항하기 위한 선천성 면역 체계를 활성화시키는데, 이러 한 비강 점막의 선천성 면역 체계에 가장 핵심이 되는 물질이 바로 인터페론이다. ${ }^{3)}$ 인터페론은 크게 type I(인터페론 알파/ 베타), II(인터페론 감마)로 나누어지며 2000년 이후 호흡기 점막 상피 세포에서 많이 분비되는 type III(인터페론 람다) 인터페론의 존재가 보고되었고 호흡기 점막에서 그 역할들 에 대한 연구가 다양하게 이루어지고 있다.) 바이러스가 점막 에 침투하면 세포 내에 존재하는 수용체에서 바이러스를 인 식하고 신호 전달 체계를 활성화시켜 선천성 면역반응이 시 작된다. 그 첫 번째 단계로 인터페론의 전사가 일어나고 바이 러스에 감염된 세포에서 인터페론의 분비가 시작되며 그 감염 된 세포는 세포 자연사(apoptosis) 과정을 통해 파괴되어 더 이 상 바이러스가 그 세포에 존재할 수 없도록 한다. 감염된 세포 에서 분비된 인터페론은 각각 type에 따른 수용체를 거쳐 감염 되지 않은 건강한 세포에 신호를 전달하게 되며 Janus kinase signal transducer and activator of transcription 신호 전달 체계를 통해 myxovirus resistance A, interferon stimulated gene 15 , oligoadenylate synthase 1 , chemokine ligand 10 , interferon-induced protein with tetratricopeptide repeats 1,2 ,3, protein kinase R 등과 같은 인터페론 유도 유전자(interferon-stimulated gene)의 과발현을 유도하고 분비된 인 터페론 유도 유전자들이 바이러스의 mRNA와 결합하여 전 사 과정을 억제하거나, 바이러스 protein의 degradation을 일
으켜 최종적으로 바이러스의 증식을 억제하고 바이러스를 사멸시키게 된다. ${ }^{78)}$ Type II 인터페론은 선천성 면역반응보 다는 후천성 면역 체계와 밀접한 관련성이 있는 것으로 알려 져 있으며, 실질적으로 비강 및 호흡기 점막의 선천성 면역 기전에는 type I과 type III 인터페론이 주로 관여한다. ${ }^{9}$ 호흡 기 점막에서는 type I 인터페론에 의해 선천성 면역 체계가 조절되고 유지된다고 알려져 있으나, 최근에 type I 인터페론 의 기능이 저하된 동물 모델이나 세포에서도 항바이러스 면역 기전이 일정 부분 유지되어 호흡기 바이러스의 사멸을 유도한 다는 연구 결과가 발표되고 있고, 이러한 기전에는 type III 인 터페론인 인터페론 람다가 중요한 역할을 한다고 생각되고 많은 추가 연구들이 실시되고 있다. ${ }^{10)}$

\section{비강 점막에서 type III 인터페론의 역할}

2010년도 이후 type I 인터페론 수용체를 knock-out 시킨 생쥐모델을 이용하여 일 연구가 진행되었는데 이러한 연구 결 과를 통해 type I 인터페론의 기능을 저하시켜도 생쥐는 인플 루엔자 A 바이러스에 저항력을 갖는다는 사실이 밝혀졌다. ${ }^{11-13)}$ 즉 type I 인터페론 외에 다른 면역 조절 물질에 의해 선천성 면역 기능이 조절될 수 있음을 증명하였고 type III 인터페론 의 중요성이 강조되기 시작하였다. Type III 인터페론의 정확 한 역할은 아직 규명되지는 않은 상태이지만 type I 인터페론 과 비슷한 메커니즘을 통해 활성화되고 type I 인터페론의 보조적 역할을 하는 것으로 추정하고 있다. 하지만 type III 인터페론의 특이 수용체가 주로 호흡기 상피 세포에 가장 많 이 분포하고 있어 현재 type III 인터페론이 호흡기 점막의 선천성 면역 기전에 중요한 역할을 하는 면역 조절 물질로 생 각된다. ${ }^{14)}$ 저자들도 비강 점막에서의 type III 인터페론의 역 할에 대한 연구 결과를 보고하였고 인플루엔자 A 바이러스 감염 억제에 type III 인터페론의 역할이 중요함을 규명하였 다. ${ }^{15)}$ 비강 점막에서 type III 인터페론은 type I 인터페론과는 다른 역할, 또는 보다 진화된 역할을 하고 실제로 비강 점막의 선천성 면역 체계 활성화와 밀접한 연관이 있을 것으로 생각 된다(Fig. 1).

\section{Reactive oxygen species and interferon}

호흡기 점막에서 생성되는 활성 산소는 크게 세 가지로 구분 되는데 가장 흔한 형태는 과산화수소(hydrogen peroxide, $\mathrm{H}_{2} \mathrm{O}_{2}$ )이고 그 외에 free radical이라고 분류되는 슈퍼옥사이 드(superoxide, $\mathrm{O}_{2}{ }^{-}$)와 하이드록시라디칼(hydroxyradical, $-\mathrm{OH})$ 이 있다. 그 개별적 기능이 명확하게 규명되지는 않았 지만 과산화수소는 주로 세포 신호 전달 체계 혹은 외부 병 원균에 대한 면역 작용에 주로 관여하는 것으로 알려졌고 슈 


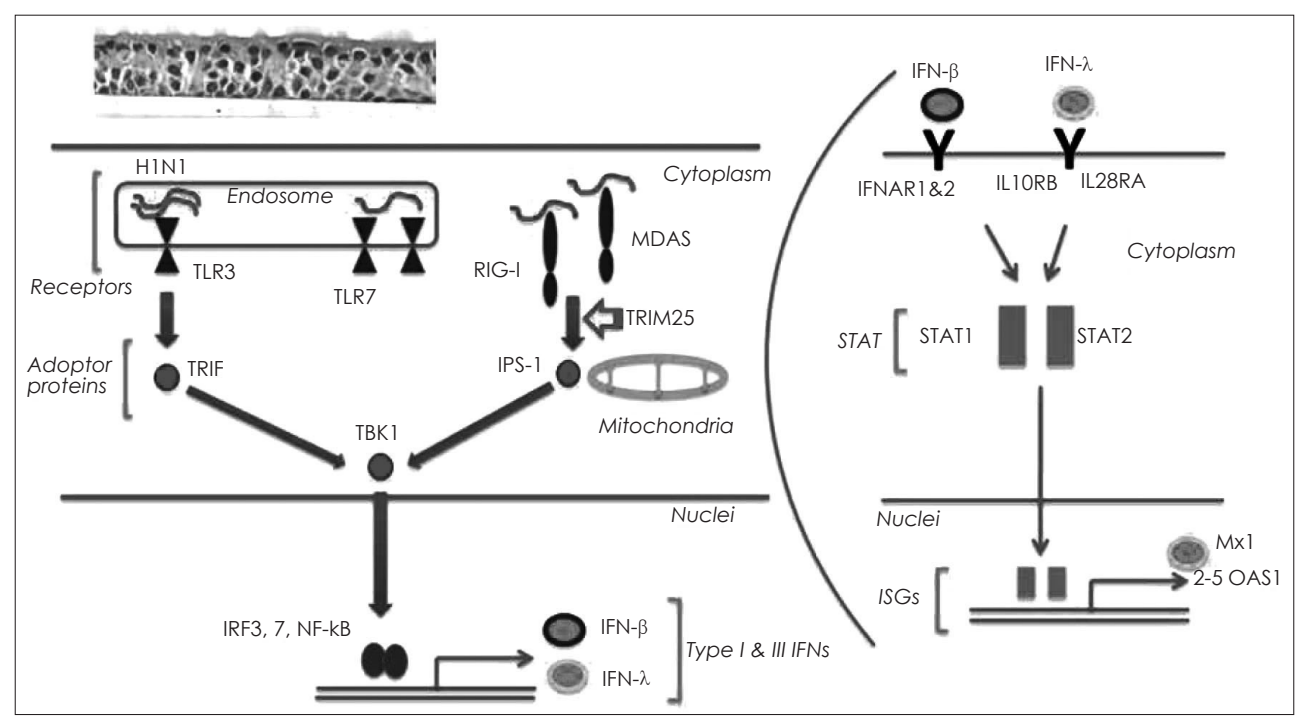

Fig. 1. The mechanism of type I and type III interferon secretion after recognition of dsRNA virus in respiratory epithelial cells. IFN: interferon, H1N1: influenza A virus subtype, TLR: toll-like receptor, RIG-I: retinoic acid-inducible gene I, MDA5: melanoma differentiation-associated protein, TRIM25: tripartite motif-containing protein 25, TRIF: TIR-domain-containing adapter-inducing interferon- $\beta$, IPS-1: interferon-promoter stimulator 1, TBK1: TANK-binding kinase 1, IRF3: interferon regulatory factor 3, NF-kB: nuclear factor kappa B, IFNAR1: interferon-alpha/beta receptor 1, IL10RB: interleukin 10 receptor beta, IL28RA: interleukin 28 receptor alpha, STAT: signal transducer and activator of transcription, ISGs: interferon-stimulated genes, Mx1: myxovirus resistance 1, 2'-5' OAS1: 2'-5' oligoadenylate synthase 1.

퍼옥사이드와 하이드록시라디칼은 세포 독성 유도 및 염증 반응에 관여하여 질병 유발 기전과 관련 있는 것으로 알려지 고 있다. 활성 산소 혹은 free radical은 세포 내에서 여러 효소 의 작용에 의해 생성이 되는데 nicotinamide adenine dinucleotide phosphate oxidase(Nox), xanthine oxidase, nitric oxide synthase, mitochondria respiratory chain reaction 등을 통해 다양한 종류의 활성 산소들이 생성된다. 현재까지 인체에서는 Nox에 의한 생성이 면역 세포 및 비면역 세포 모 두에서 주된 기전으로 알려져 있는데 지금까지는 면역 세포 에서의 활성 산소 생성 기전에 대한 연구가 다양하게 발표되 고 있다. ${ }^{16,17)}$ Macrophage 등에서 박테리아를 포식하게 되면 Nox, 특히 Nox2가 활성화되어 활성 산소를 생성하고 균주 의 증식을 억제시킨다고 알려져 있다. 지금까지 Nox는 주로 소 화기 상피 세포 및 macrophage 등의 면역 세포에서 활성 산소 생성 기전이 주로 연구되었는데, 최근에는 여러 Nox subfamily가 비면역 세포에서도 발견되고 있고 Nox1, Nox2, Nox3, Nox4, Nox5, Duox1, Duox2 같은 subfamily들이 인체 내의 소화기 외의 점막 상피 세포를 포함한 비면역 세포에서 활성 산소 생성을 하고 있음이 알려지고 있다. ${ }^{18)}$

Nox의 한 subtype인 Duox는 특히 호흡기 상피 세포에서 주로 발현을 한다고 알려져 있어 호흡기 질환이나 면역 기전 에 미치는 Duox의 영향에 대한 연구 결과가 많이 보고되고 있다. Duox1은 자극에 상관없이 항상 호흡기 상피 세포에 분 포하며 일정량의 활성 산소를 만들어 내지만 Duox2는 외부
병원체, 알러젠, 특정 자극 등에 호흡기 상피 세포가 노출되 면 유전자와 단백질 발현이 증가하며 활성 산소를 생성한다. 특히 Duox2에 의해 생성되는 활성 산소는 면역 증가 기전과 의 연관성이 알려지고 있는데 비면역 세포에서의 활성 산소의 생성 및 균주 억제 역할을 한다고 알려져 있어 Duox2의 구체 적인 역할과 활성 산소 생성 기전에 대한 연구가 점막 면역 체 계의 연구에 매우 중요하다고 생각된다.

비강 점막에서도 Duox1, Duox2의 발현이 증가되어 있으며 항상성 유지 및 외부 자극에 반응하여 활성 산소를 생성하 는데 이 두 효소 외에도 Nox4가 비강 점막에서는 중요한 역 할을 한다고 생각된다. 특히 Nox4는 코상피 세포에서 점액분 비세포에 주로 발현하며 세포에 염증을 유발할 수 있는 환경 혹은 자극에 노출되면 활성 산소의 생성이 증가되며 점액의 분비를 촉진하는 것으로 알려져 있다. 비강 점막에서도 Duox1, Duox2가 가장 많이 분포되어 있지만 외부 자극에 대해 반응 하여 활성 산소를 생성하는 inducibility는 Nox4가 가장 큰 것으로 보고되었고 비강 점막에서의 활성 산소 생성 효소의 다양성과 구체적인 역할, 특히 선천성 면역기전과의 관련성에 대한 추가 연구가 필요하다고 생각된다. ${ }^{19,20)}$

활성 산소는 지금까지 인체에 스트레스를 일으키는 물질로 잘 알려져 있었으며 특히 과도한 산소 노출이나 저산소 자극 이 지속되면 free radical이 생성되어 다양한 염증반응 및 세 포 노화를 일으켜 만성 질환의 원인이 될 수 있음이 보고되고 있다. 하지만 이러한 염증반응 외에도 바이러스나 박테리아의 
사멸에 관여하여 선천성 또는 후천성 면역반응과 관계가 있 는 것으로 최근 밝혀지고 있어 그 기능에 대한 논의가 지속되 고 있다. Nox 외에도 미토콘드리아에서도 활성 산소가 생성 되는데 아직 호흡기 상피 세포에서의 역할에 대해서는 많이 연구되어 있지 않지만 최근에 autophagy와 미토콘드리아에 서 생성된 활성 산소의 연관성이 활발히 연구되고 있고 항바 이러스 기전 및 선천성 면역 체계와 밀접한 관련성이 있을 것 이라는 연구 결과가 발표되고 있다. ${ }^{21,22)}$

비강 점막에서도 활성 산소가 항바이러스 면역기전과 밀 접한 연관이 있는 것으로 생각되며 바이러스 감염 후에 발생 한 활성 산소의 생성을 억제시키거나 활성 산소 생성 효소의 활성화를 줄이면 호흡기 점막에서 선천성 면역 체계에 주된 역 할을 하는 인터페론의 활성화가 감소되며 interferon-stimulating gene의 발현이 줄어들어 바이러스 감염에 취약해지고 감염이 더 심각해진다고 보고되었다. 특히 미토콘드리아 및 다른 활성 산소 생성 체계보다는 Nox system에 의한 활성 산 소 생성이 항바이러스 기전과 더 밀접한 것으로 생각되며 특 히 Duox2의 역할이 중요할 것으로 생각된다. ${ }^{23,24)}$ 결국 외부 의 박테리아 및 바이러스 등이 침투하면 우리 몸의 면역 체 계가 활성화 되는데, 기존의 면역 세포에서 중요한 역할을 하 는 활성 산소의 생성이 외부 균주에 일차적으로 대응하는 비 강 점막에서도 활성화되고 Nox system이 면역 체계의 활성화 및 외부 균주, 특히 바이러스를 사멸 기전에 필수적이라고 알 려지고 있다. Nox system을 이용한 선천성 면역 체계 강화 기 전에 대한 연구가 앞으로 더 활발히 진행될 것으로 기대되며 항바이러스 약제 개발 및 점막 면역 백신 연구에 더 많은 기여 를 할 것으로 생각된다.

\section{결 론}

비강 점막에서 활성 산소의 구체적 역할에 대해서 아직 완 전히 밝혀지지는 않은 상태이지만 기존에 여러 연구에서 알려 진 것처럼 만성 염증성 질환을 유도하는 것뿐 아니라 선천성 면역 기전을 매개하는 역할도 하는 것으로 생각된다. 활성산 소는 생성하는 효소가 명확히 밝혀져 있고 생화학적으로 조 절이 용이한 장점이 있어 향후 면역 유도 물질로서의 개발이 가능할 것으로 기대된다. 활성 산소는 특히 type III 인터페론 과 그 밀접한 상관관계(Fig. 1)가 있는 것으로 생각되어 향후 다양한 연구를 통해 비강 점막에서 차별화된 항바이러스 기 전 및 선천성 면역 기능 유지 역할이 규명될 것으로 판단된다.

\section{REFERENCES}

1) Kawai $T$, Akira $S$. Innate immune recognition of viral infection.
Nat Immunol 2006;7(2):131-7.

2) Yoneyama M, Kikuchi M, Natsukawa T, Shinobu N, Imaizumi T, Miyagishi M, et al. The RNA helicase RIG-I has an essential function in double-stranded RNA-induced innate antiviral responses. Nat Immunol 2004;5(7):730-7.

3) García-Sastre A, Biron CA. Type 1 interferons and the virus-host relationship: a lesson in détente. Science 2006;312(5775):879-82.

4) Horimoto T, Kawaoka Y. Influenza: lessons from past pandemics, warnings from current incidents. Nat Rev Microbiol 2005;3(8):591600.

5) Levy DE, Darnell JE Jr. Stats: transcriptional control and biological impact. Nat Rev Mol Cell Biol 2002;3(9):651-62.

6) Wakim LM, Gupta N, Mintern JD, Villadangos JA. Enhanced survival of lung tissue-resident memory CD $8+\mathrm{T}$ cells during infection with influenza virus due to selective expression of IFITM3. Nat Immunol 2013;14(3):238-45.

7) Onomoto K, Yoneyama M, Fung G, Kato H, Fujita T. Antiviral innate immunity and stress granule responses. Trends Immunol 2014;35(9): 420-8.

8) Schoggins JW, Rice CM. Interferon-stimulated genes and their antiviral effector functions. Curr Opin Virol 2011;1(6):519-25.

9) Mihm S. Activation of Type I and Type III Interferons in Chronic Hepatitis C. J Innate Immun 2015;7(3):251-9.

10) Ludwig S, Wolff T. Influenza A virus TRIMs the type I interferon response. Cell Host Microbe 2009;5(5):420-1.

11) Haller $\mathrm{O}$, Kochs G, Weber F. The interferon response circuit: induction and suppression by pathogenic viruses. Virology 2006;344(1):119-30.

12) Mahlakõiv T, Hernandez $P$, Gronke K, Diefenbach A, Staeheli P. Leukocyte-derived IFN- $\alpha / \beta$ and epithelial IFN- $\lambda$ constitute a compartmentalized mucosal defense system that restricts enteric virus infections. PLoS Pathog 2015;11(4):e1004782.

13) Lebreton A, Lakisic G, Job V, Fritsch L, Tham TN, Camejo A, et al. A bacterial protein targets the BAHD1 chromatin complex to stimulate type III interferon response. Science 2011;331(6022):1319-21.

14) Edwards MR, Regamey N, Vareille M, Kieninger E, Gupta A, Shoemark A, et al. Impaired innate interferon induction in severe therapy resistant atopic asthmatic children. Mucosal Immunol 2013; 6(4):797-806.

15) Kim HJ, Kim CH, Ryu JH, Kim MJ, Park CY, Lee JM, et al. Reactive oxygen species induce antiviral innate immune response through IFN- $\lambda$ regulation in human nasal epithelial cells. Am J Respir Cell Mol Biol 2013;49(5):855-65.

16) van der Vliet A. NADPH oxidases in lung biology and pathology: host defense enzymes, and more. Free Radic Biol Med 2008;44(6): 938-55.

17) Rhee SG. Cell signaling. $\mathrm{H} 2 \mathrm{O} 2$, a necessary evil for cell signaling. Science 2006;312(5782):1882-3.

18) Liu T, Castro S, Brasier AR, Jamaluddin M, Garofalo RP, Casola A. Reactive oxygen species mediate virus-induced STAT activation: role of tyrosine phosphatases. J Biol Chem 2004;279(4):2461-9.

19) Kim HJ, Park YD, Moon UY, Kim JH, Jeon JH, Lee JG, et al. The role of Nox4 in oxidative stress-induced MUC5AC overexpression in human airway epithelial cells. Am J Respir Cell Mol Biol 2008; 39(5):598-609.

20) Kim HJ, Kim CH, Ryu JH, Joo JH, Lee SN, Kim MJ, et al. Crosstalk between platelet-derived growth factor-induced Nox4 activation and MUC8 gene overexpression in human airway epithelial cells. Free Radic Biol Med 2011;50(9):1039-52.

21) Arnoult D, Carneiro L, Tattoli I, Girardin SE. The role of mitochondria in cellular defense against microbial infection. Semin Immunol 2009; 21(4):223-32.

22) West AP, Shadel GS, Ghosh S. Mitochondria in innate immune responses. Nat Rev Immunol 2011;11(6):389-402.

23) Lipinski S, Till A, Sina C, Arlt A, Grasberger H, Schreiber S, et al. 
DUOX2-derived reactive oxygen species are effectors of NOD2mediated antibacterial responses. J Cell Sci 2009;122(Pt 19):3522-30. 24) Fialkow L, Wang Y, Downey GP. Reactive oxygen and nitrogen species as signaling molecules regulating neutrophil function. Free Radic Biol Med 2007;42(2):153-64.

\section{정답 및 해설}

답 (1)

해 설 재발성 다발연골염이 의심되는 환자로, 연골조직과 결합조직에 발생하는 염증을 특징으로 하는 자가면역성 질환이다. 감 각신경성 난청, 전도성 난청, 전정기능저하 등 다양한 양상을 보일 수 있다. 스테로이드 치료 혹은 면역억제제를 이용한 치료를 고려할 수 있다.

References: 1. Arts HA. Sensorineural Hearing Loss in Adults. In: Flint PW, Haughey BH, Niparko JK, Richardson MA, Lund VA, Robbins KT, et al., editors. Cummings Otolaryngology-Head and Neck Surgery. 5th ed. Philadelphia: Mosby;2010. p.2124.

2. Rha KS. Otorhinolaryngology-Head and neck surgery. 2nd ed. Seoul: lljogak;2009. p.552. 